Review/Meta-analyses

\title{
Early life experiences and social cognition in major psychiatric disorders: A systematic review
}

\author{
Karolina I. Rokita, Maria R. Dauvermann, Gary Donohoe* \\ School of Psychology \& Centre for Neuroimaging \& Cognitive Genomics, National University of Ireland, Galway, Ireland
}

\section{A R T I C L E I N F O}

\section{Article history:}

Received 20 March 2018

Received in revised form 18 June 2018

Accepted 19 June 2018

\section{Keywords:}

Environment

Early-life adversity

Attachment

Social cognition

Psychiatric disorders

Schizophrenia

\begin{abstract}
A B S T R A C T
Objective: To present a systematic review of the literature on the associations between early social environment, early life adversity, and social cognition in major psychiatric disorders, including schizophrenia, bipolar disorder, borderline personality disorder, major depressive disorder and posttraumatic stress disorder.

Method: Relevant studies were identified via electronic and manual searches of the literature and included articles written in English and published in peer-reviewed journals up to May 2018. Quality assessment was performed using the quality evaluation scale employed in previous systematic reviews. Results: A total of 25 studies were included in the systematic review with the quality assessment scores ranging from 3 to 6 (out of 6 ). The vast majority of the studies reviewed showed a significant association between early childhood social experience, including both insecure attachment and adversity relating to neglect or abuse, and poorer social cognitive performance.

Conclusion: We discuss these findings in the context of an attachment model, suggesting that childhood social adversity may result in poor internal working models, selective attention toward emotional stimuli and greater difficulties with emotional self-regulation. We outline some of the steps required to translate this understanding of social cognitive dysfunction in major psychiatric disorders into a target for interventions that mitigate the adverse effects of childhood maltreatment and poor parental attachment on social cognition.
\end{abstract}

(C) 2018 Elsevier Masson SAS. All rights reserved.

\section{Introduction}

Childhood adversity is highly prevalent worldwide, affecting about one third of the general population [1,2], and contributing to a number of negative outcomes in later life, including higher rates of criminal behaviour [3], alcohol and drug use [4], and lower academic achievement [5]. Adverse childhood experiences have been identified as major risk factors for the development of many psychiatric disorders, such as schizophrenia, bipolar disorder, borderline personality disorder, major depressive disorder and posttraumatic stress disorder [6-9]. Specifically, childhood trauma - often defined in terms of physical and emotional neglect, and physical, emotional, and sexual abuse - has been a particular focus of research because of their deleterious and long-lasting effects [10]. The types and frequencies of these traumatic experiences can have a negative impact on mental health in adulthood [11]. In fact, traumatic experiences in childhood are frequently reported to show increased prevalence in patients with psychiatric disorders,

\footnotetext{
* Corresponding author.

E-mail address: gary.donohoe@nuigalway.ie (G. Donohoe).
}

with rates as high as $85 \%$ in schizophrenia spectrum disorders [12], $82 \%$ in personality disorders [13], $77 \%$ in affective disorders including major depressive disorder and bipolar disorder [12], and $70 \%$ in patients with posttraumatic stress disorder [14]. Emotional abuse and neglect appear to represent the most common forms of childhood maltreatment $[15,16]$.

In addition to childhood maltreatment, a number of other types of adverse early life experiences, such as early loss of caregivers and insecure attachment styles (i.e. dismissive-avoidant, fearfulavoidant and anxious-pre-occupied [17]) have also been related to psychopathology in adulthood [18-20]. The link between childhood trauma and insecure attachment has been supported by a number of studies showing that a history of childhood trauma is significantly positively associated with attachment insecurities in later life [21-24], indicating significant overlap between these experiences. This suggests that adverse childhood experiences may provoke the development of insecure types of attachment. According to Fonagy [25], childhood trauma is the most destructive factor in the development of the attachment system.

The importance of attachment was emphasised by Bowlby [26], who argued that the relationships and bonds between parents and their offspring are critical for children's cognitive, emotional and 
social development. Specifically, he claimed that insensitive, maltreating and neglectful parenting negatively influences individuals' interpretations and expectations, and results in construction of an unworthy and inadequate internal working model of relationships [27]. This attachment structure not only integrates past experiences, but also provides the basis on which to form expectations for later relationships. Exposure to inconsistent and unreliable attachment figures, as well as the experience of childhood trauma, can negatively affect a child's sense of safety and security, essential to the development of secure attachment and positive mental representations of self and others [28]. Specifically, the first 3 years of life are a very sensitive period for the development of the attachment relationships and exposure to traumatic events during this time has irreversible effects on subsequent cognitive, social and emotional development $[26,27,29]$. Once an attachment pattern is formed in childhood, it tends to persist beyond youth [30].

Of relevance to social cognitive development, Bowlby's [31] 'defensive exclusion' hypothesis posits that insecurely attached individuals will filter out all information related to his/her attachment figure, as this is associated with emotional pain. Even positive attachment-related information will be prohibited from entering conscious awareness as it protects individuals from experiencing psychological pain associated with the notion that they have no or very little positive experiences with their attachment figure [32]. As a result of this selective or 'biased' information processing an individual also lacks integrated memories of negative states, which in turn may impact their Theory of Mind (ToM) development [33]. Without the proper use and reflection of positive and negative mental states within one's own mind, making correct inferences about another person's beliefs or intentions can also be impaired.

Also relevant to social cognitive development, children with the experience of abuse may also be more likely to develop an enhanced sensitivity to social cues that are reminiscent of the adults who abused them [34]. Consequently, maltreated individuals may become more vigilant and distracted by threatening stimuli ('threat-related attention bias') [35], thus failing to adequately process peripheral cognitive and social information. There is also substantial evidence that maltreating parents provide less affective interactions as compared to non-abusive parents and tend to isolate themselves and their children from social interactions, providing no stable models for forming close relationships in later life [36-39]. Specifically, those children who develop an avoidant attachment pattern would be expected to show fearfulness and avoidance in social situations, so that they are less likely to develop adequate representations of the social environment and expressions needed to accurately recognise others' emotions.

Supporting these hypotheses, a number of studies in children have shown that exposure to adverse environments interferes with the development of social cognition [40-42], which refers to the set of mental operations underlying social interactions, and in psychiatric studies generally comprises the following domains: (1) emotion recognition and regulation, (2) ToM, (3) attributional style, and (4) social perception. Deficits in social cognitive function are a hallmark feature of major psychiatric disorders resulting in impaired social and occupational functioning [43,44].

Despite the relevance of early life experience to understanding development of social cognition in those who go on to experience psychiatric disorders, the association between early life experiences and social cognition in psychiatric disorders remains poorly understood. To synthesise what is currently known, we undertook a systematic review of the existing literature on the relationships between childhood experiences of adversity, attachment (both secure and insecure) and social cognition in adults with major psychiatric disorders, including schizophrenia (SZ), bipolar disorder (BD), borderline personality disorder (BPD), major depressive disorder (MDD) and posttraumatic stress disorder (PTSD).

\section{Methods}

\subsection{Search strategy}

An electronic search was conducted using PubMed and PsycINFO to identify original articles addressing the relationship between adverse early life experiences, attachment and social cognitive measures in adults with major psychiatric disorders, published up to May 2018. The following terms were used as search terms ((emotion recognition OR self-regulation OR theory of mind OR attribution OR facial expression OR face perception OR social cognition OR social perception OR face discrimination OR emotion regulation OR emotion perception OR social inference) AND (parent death OR institutional care OR foster care OR physical abuse OR verbal abuse OR sexual abuse OR emotional abuse OR domestic violence OR parent divorce OR parental mental illness OR neglect OR parental alcoholism OR parental maltreatment OR adversities OR childhood trauma OR attachment OR early life stress OR parental bonding OR adverse childhood experience OR childhood adversity) AND (schizophrenia OR schizoaffective disorder OR psychosis OR bipolar disorder OR borderline personality disorder OR major depressive disorder OR posttraumatic stress disorder)). We included only studies that assessed the direct relationship between adverse early life experiences (e.g. childhood trauma) and/or attachment and social cognition (e.g. theory of mind, emotion recognition) in adult patients with schizophrenia spectrum disorders, bipolar disorder, borderline personality disorder, major depressive disorder and/or posttraumatic stress disorder. Searches were limited to original articles written in English and published in peer-reviewed journals up to May 2018. Neuroimaging studies were excluded.

\subsection{Quality assessment}

The quality assessment was based on the revised version of the quality evaluation scale employed in previous systematic reviews [45,46], and comprised the following items: (1) The clinical sample was representative of the target population (eligible cases were recruited in hospitals and/or mental health services settings with a diagnosis based on well-established clinical diagnostic manuals), (2) The clinical sample was appropriately matched to the control group (patients and controls matched for at least two confounding variables: age and/or sex and/or education level and/or body mass index), (3) The authors performed sample size calculations and/or power analysis, (4) The study used well-established measures of early life stress and attachment styles, (5) The study used wellestablished measures of social cognition, (6) The authors reported effect sizes and/or confidence intervals of their main findings. Each item scored one point if the criterion was met (i.e. present) and the overall quality score was calculated by adding up all the items.

\subsection{Study characteristics}

The literature search identified 2619 relevant publications of which 20 were found to meet criteria for inclusion after examining the titles and abstracts. Based on a review of the reference list of these papers a further five published studies met the inclusion criteria. In total 25 publications were included. These included nine studies conducted in patients with schizophrenia spectrum disorders, two studies included patients with bipolar disorder, six studies of patients with borderline personality disorder, three studies of patients with posttraumatic stress disorder, one study 
which included borderline personality disorder and bipolar disorder patients, one was performed on borderline personality disorder and major depressive disorder patients, two on patients with major depressive disorder and one was carried out in patients with borderline personality disorder plus additional personality disorders. Studies focused only on healthy participants were not included in this review; however, in patient studies in which a healthy comparison group was included, the data from these groups are reported. The PRISMA flow diagram is presented in Fig. 1 [47] and the relevant studies are presented in Table 1.

\section{Results}

\subsection{Quality evaluation}

The quality of the 25 studies included in this systematic review was assessed by two independent reviewers and is presented in Supplementary Table 1 . The scores ranged from 3 to 6 points (out of 6 ) in the quality assessment instrument. All of the studies recruited clinical populations in hospitals and mental health services, and their diagnosis was confirmed using well-established clinical diagnostic manuals (e.g. Structured Clinical Interview for DSM-IV (SCID) [73])). Only three studies reported performing sample size calculations and/or power analysis $[50,71,74]$ and six studies used a sample size of less than 30 patients [52,56,60,63-65], thus limiting the generalisability of findings. Other methodological flaws included either poorly matched control groups [52,54,61] or no control groups at all $[51,53,57,58,63,67,69,70,74,75]$. The majority of the studies employed well-established measures of early life stress and attachment (e.g. Childhood Trauma
Questionnaire (CTQ) [76], Relationship Questionnaire [77])) and social cognition (e.g. Reading the Mind in the Eyes Task [78], Emotion Recognition Task [79]) providing a valid description of the childhood experiences and social cognitive functioning. Less than half of the studies $[48,49,51-53,57,60,61,63,64,71,74]$ reported the effect sizes and/or the confidence intervals of the main statistical analyses affecting the interpretation of the findings.

\subsection{Early social environment and social cognition in major psychiatric disorders}

\subsubsection{Schizophrenia spectrum disorders}

We identified a total of nine studies that investigated the impact of early life environment on social cognition in patients with schizophrenia spectrum disorders.

In a study of 34 patients with first-episode psychosis (FEP) MaBeth et al. [69] showed that patients classified as having an insecure/dismissing (avoidant) attachment style had significantly lower scores on a measure of emotional ToM than patients with either a secure or an insecure/preoccupied (anxious) attachment style. However, the generalisability of these results was limited by the small sample size, particularly of patients with an insecurepreoccupied attachment style, and the absence of a healthy participant group. In terms of established illness, Donohoe et al. [72] examined the association between relationship style, an adult indicator of early childhood attachment, and attributional style in 73 patients with schizophrenia or schizoaffective disorder and 78 healthy controls. The authors found that lower 'personalising bias' (attributing negative events to others rather than to situational factors) was predicted by higher secure relationship style ratings in

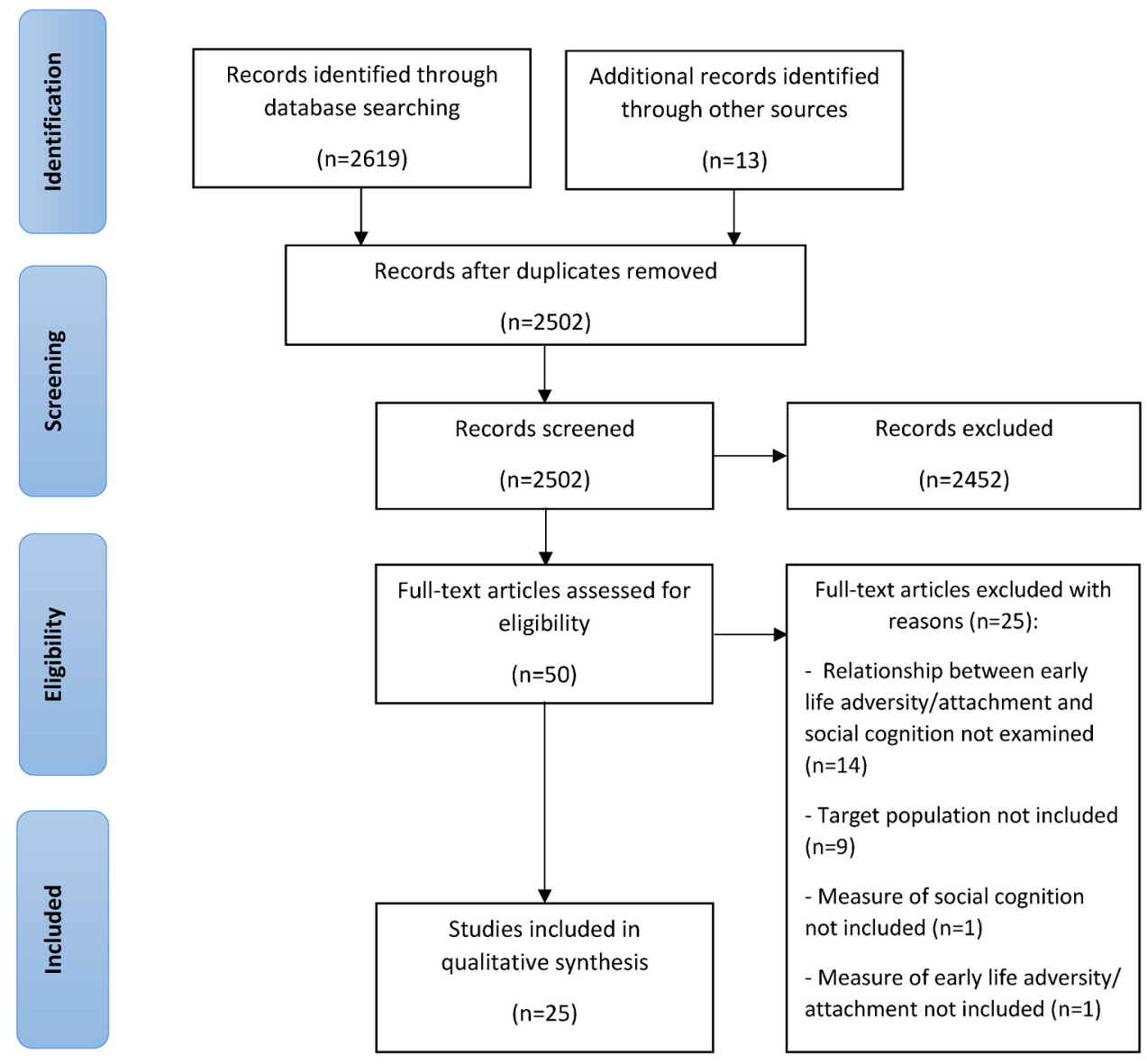

Fig. 1. Prisma flow diagram of studies selected for systematic review. 
Table 1

Characteristics of the studies included in the review.

\begin{tabular}{|c|c|c|c|c|c|c|}
\hline Study & $\begin{array}{l}\text { Participants } \\
\mathrm{N} \text { (male: } \\
\text { female) }\end{array}$ & $\begin{array}{l}\text { Age } \\
\text { Mean (SD) }\end{array}$ & $\begin{array}{l}\text { Environmental } \\
\text { measures }\end{array}$ & Social cognitive measures & Main findings & $\begin{array}{l}\text { Quality } \\
\text { assessment } \\
\text { total score }\end{array}$ \\
\hline $\begin{array}{l}\text { Schalinski } \\
\text { et al., } \\
\text { (2017) } \\
{[48]}\end{array}$ & $\begin{array}{l}\text { Patients with } \\
\text { psychosis }=168 \\
(112: 56) \\
\text { HC }=50(28: 22)\end{array}$ & $\begin{array}{l}\text { Patients with } \\
\text { psychosis }=27.9 \\
(8.4) \\
\text { HC }=26.8 \text { (7.9) }\end{array}$ & MACE & MCCB & $\begin{array}{l}\text { Cumulative adverse childhood experiences and } \\
\text { physical neglect at age } 11 \text { were significantly } \\
\text { negatively associated with social cognition in } \\
\text { patients. }\end{array}$ & 5 \\
\hline $\begin{array}{l}\text { Kilian et al., } \\
\text { (2017) } \\
{[49]}\end{array}$ & $\begin{array}{l}\mathrm{FEP}=56(42: 14) \\
\mathrm{HC}=52(35: 17)\end{array}$ & $\begin{array}{l}\mathrm{FEP}=23.8(6.2) \\
\mathrm{HC}=25.1(6.8)\end{array}$ & CTQ & MCCB & $\begin{array}{l}\text { Childhood neglect was significantly correlated } \\
\text { with social cognitive impairments in both } \\
\text { patients and controls. These associations were } \\
\text { stronger in the patient group. }\end{array}$ & 5 \\
\hline $\begin{array}{l}\text { Koelkebeck } \\
\text { et al., } \\
\text { (2017) } \\
\text { [50] }\end{array}$ & $\begin{array}{l}\text { MDD = } 38 \\
(21: 17) \\
\mathrm{HC}=40(23: 17)\end{array}$ & $\begin{array}{l}\mathrm{MDD}=40.3(11.4) \\
\mathrm{HC}=39.7(10.9)\end{array}$ & AAS & 'animated triangles' task & $\begin{array}{l}\text { Insecure attachment style (i.e. anxious, } \\
\text { dependent) was significantly associated with } \\
\text { ToM deficits in patients. }\end{array}$ & 5 \\
\hline $\begin{array}{l}\text { Jiménez } \\
\text { et al., } \\
\text { (2017) } \\
{[51]}\end{array}$ & $\begin{array}{l}\mathrm{LP} B D=10 \\
(4: 6)^{*} \\
\mathrm{AP} \mathrm{BD}=74 \\
(31: 43)^{*} \\
\mathrm{HP} \mathrm{BD}=29 \\
(11: 17)^{*}\end{array}$ & $\begin{array}{l}\mathrm{LP} \mathrm{BD}=52.0 \\
(15.28)^{*} \\
\mathrm{AP} \mathrm{BD}=48.23 \\
(11.37)^{*} \\
\mathrm{HP} \mathrm{BD}=45.24 \\
(10.7)^{*}\end{array}$ & CTQ & MSCEIT-ME & $\begin{array}{l}\text { No significant associations were reported } \\
\text { between childhood trauma and social cognition. }\end{array}$ & 4 \\
\hline $\begin{array}{l}\text { Palmier- } \\
\text { Claus } \\
\text { et al., } \\
2016[52]\end{array}$ & $\begin{array}{l}\mathrm{SZ}=20(13: 7) \\
\mathrm{FEP}=20(16: 4) \\
\mathrm{UHR}=14(6: 8) \\
\mathrm{HC}=120 \\
(35: 85)\end{array}$ & $\begin{array}{l}\mathrm{SZ}=39.6(8.9) \\
\mathrm{FEP}=24.6(5.2) \\
\mathrm{UHR}=22.6(5.2) \\
\mathrm{HC}=20.1(2.5)\end{array}$ & CTQ; PAM & Hinting Task; RMET & $\begin{array}{l}\text { No significant effects of childhood trauma on } \\
\text { either measure of ToM were reported. }\end{array}$ & 4 \\
\hline $\begin{array}{l}\text { Olbert } \\
\text { et al.,2016 } \\
\text { [53] }\end{array}$ & $\begin{array}{l}S Z=138(102: \\
36)\end{array}$ & $\mathrm{SZ}=41.3(12.5)$ & PAM & $\begin{array}{l}\text { SCAF paradigms; AIHQ (the } \\
\text { blame bias subscale); Facial } \\
\text { Affect Identification }\end{array}$ & $\begin{array}{l}\text { No significant correlations between attachment } \\
\text { and social cognitive measures were found. }\end{array}$ & 3 \\
\hline $\begin{array}{l}\text { Garcia et al., } \\
2016 \text { [54] }\end{array}$ & $\begin{array}{l}\text { Early psychosis } \\
\text { patients }=79 \\
(48: 31) \\
\mathrm{HC}=58(30: 28)\end{array}$ & $\begin{array}{l}\text { Early psychosis } \\
\text { patients } \\
\text { (male) }=24.4 \\
(4.5) \\
\text { Early psychosis } \\
\text { patients } \\
\text { (female) }=26.8 \\
(5.9) \\
\text { HC (male) }=24.0 \\
(4.8) \\
\text { HC } \\
(\text { female })=23.9 \\
(4.2)\end{array}$ & CTQ & MSCEIT-ME & $\begin{array}{l}\text { A history of childhood trauma was associated } \\
\text { with poorer social cognition in patients. }\end{array}$ & 3 \\
\hline $\begin{array}{l}\text { Brüne } \\
\text { et al.,2016 } \\
\text { [55] }\end{array}$ & $\begin{array}{l}\mathrm{BPD}=30 \text { (all } \\
\text { female) } \\
\mathrm{HC}=30 \text { (all } \\
\text { female) }\end{array}$ & $\begin{array}{l}\mathrm{BPD}=25.7(6.3) \\
\mathrm{HC}=25.3(7.7)\end{array}$ & $\begin{array}{l}\text { CTQ; Parental } \\
\text { Rearing Style } \\
\text { Questionnaire } \\
\text { (German version - } \\
\text { FEE); RQ }\end{array}$ & $\begin{array}{l}\text { Cartoon-based mentalization } \\
\text { task }\end{array}$ & $\begin{array}{l}\text { Significant correlations between childhood } \\
\text { trauma, recalled parenting, attachment and } \\
\text { performance on the mentalizing task were } \\
\text { reported in the patient group. } \\
\text { No CTQ or FEE data were recorded for the control } \\
\text { group. }\end{array}$ & 4 \\
\hline $\begin{array}{l}\text { Petersen } \\
\text { et al., } \\
2016[56]\end{array}$ & $\begin{array}{l}\mathrm{BPD}=19(1: 18) \\
\mathrm{HC}=20(1: 19)\end{array}$ & $\begin{array}{l}\mathrm{BPD}=33.0 \\
(14.27) \\
\mathrm{HC}=32.5(13.57)\end{array}$ & CAT & $\begin{array}{l}\text { RMET; EAT; False-Belief } \\
\text { Picture Sequencing Task - } \\
\text { short version; Joke- } \\
\text { Appreciation Task; Faux Pas } \\
\text { Task }\end{array}$ & $\begin{array}{l}\text { Childhood experiences of punishment were } \\
\text { significantly associated with decreased } \\
\text { mentalization ability in adulthood. }\end{array}$ & 4 \\
\hline $\begin{array}{l}\text { Beeney } \\
\text { et al., } \\
\text { (2015) } \\
\text { [57] }\end{array}$ & $\begin{array}{l}\mathrm{BPD}=150(98: \\
52)\end{array}$ & $\mathrm{BPD}=44.9(10.4)$ & ECR-R & $\begin{array}{l}\text { PAI-BOR;DERS; IIP; clinician's } \\
\text { assessment of mentalization }\end{array}$ & $\begin{array}{l}\text { Anxious and avoidant attachment were } \\
\text { significantly associated with mentalization } \\
\text { difficulties. }\end{array}$ & 4 \\
\hline $\begin{array}{l}\text { Günther } \\
\text { et al.,2015 } \\
\text { [58] }\end{array}$ & $\begin{array}{l}\text { MDD = } 45 \\
(15: 30)\end{array}$ & $\begin{array}{l}\mathrm{MDD}=34.04 \\
(9.48)\end{array}$ & CTQ & Dot-Probe task & $\begin{array}{l}\text { A history of emotional abuse and physical } \\
\text { neglect was significantly associated with } \\
\text { attentional bias scores to sad faces. }\end{array}$ & 3 \\
\hline $\begin{array}{l}\text { Russo } \\
\text { et al.,2015 } \\
\text { [59] }\end{array}$ & $\begin{array}{l}\text { BD (type I: } 52 ; \\
\text { type II: } 22)=75 \\
(51: 24)\end{array}$ & $\mathrm{BD}=47.1(10.2)$ & CTQ & ERT & $\begin{array}{l}\text { A history of childhood trauma, specifically } \\
\text { emotional neglect and physical abuse, was } \\
\text { significantly associated with a decreased ability } \\
\text { to recognise anger. }\end{array}$ & 3 \\
\hline $\begin{array}{l}\text { Nazarov } \\
\text { et al., } \\
(2015) \\
{[60]}\end{array}$ & $\begin{array}{l}\mathrm{PTSD}=29 \text { (all } \\
\text { female) } \\
\mathrm{HC}=21 \text { (all } \\
\text { female) }\end{array}$ & $\begin{array}{l}\text { PTSD = } 42.0 \\
(12.3) \\
\mathrm{HC}=39.9(14.7)\end{array}$ & CTQ & $\begin{array}{l}\text { Two computer-based tasks } \\
\text { assessing affective prosody: } \\
\text { recognition } \\
\text { and discrimination }\end{array}$ & $\begin{array}{l}\text { A history of childhood trauma was associated } \\
\text { with emotion recognition and discrimination } \\
\text { difficulties in patients. }\end{array}$ & 4 \\
\hline $\begin{array}{l}\text { Pos } \\
\text { et al.,2015 } \\
\text { [61] }\end{array}$ & $\begin{array}{l}\mathrm{SZ}=111(92: 19) \\
\text { Siblings }{ }^{* *}= \\
106(47: 59) \\
\mathrm{HC}=63(43: 20)\end{array}$ & $\begin{array}{l}\mathrm{SZ}=31.1(7.57) \\
\text { Siblings }^{* * *}=30.81 \\
(7.98) \\
\mathrm{HC}=30.65(10.6)\end{array}$ & CTQ - SF; PAM & $\mathrm{CBE}$ & $\begin{array}{l}\text { Avoidant attachment (measured with the } \\
\text { Psychosis Attachment Measure; PAM) showed a } \\
\text { U-shaped association with affective ToM (first } \\
\text { order and second order) as well as cognitive ToM } \\
\text { (second order) indicating worse ToM } \\
\text { performance at medium scores and better ToM } \\
\text { performance at lower and higher scores on } \\
\text { avoidant attachment in patients. } \\
\text { Anxious attachment was significantly }\end{array}$ & 3 \\
\hline
\end{tabular}


Table 1 (Continued)

\begin{tabular}{|c|c|c|c|c|c|c|}
\hline Study & $\begin{array}{l}\text { Participants } \\
\mathrm{N} \text { (male: } \\
\text { female) }\end{array}$ & $\begin{array}{l}\text { Age } \\
\text { Mean (SD) }\end{array}$ & $\begin{array}{l}\text { Environmental } \\
\text { measures }\end{array}$ & Social cognitive measures & Main findings & $\begin{array}{l}\text { Quality } \\
\text { assessment } \\
\text { total score }\end{array}$ \\
\hline $\begin{array}{l}\text { Powers } \\
\text { et al., } \\
\text { (2015) } \\
{[62]}\end{array}$ & $\begin{array}{l}\operatorname{PTSD}^{* * *}=67(\text { all } \\
\text { female) }\end{array}$ & NR & TEI; CTQ & $\begin{array}{l}\text { Emotional Conflict } \\
\text { Regulation Behavioral Task }\end{array}$ & $\begin{array}{l}\text { negatively associated with cognitive ToM } \\
\text { (second order) in patients. } \\
\text { No significant differences were found between } \\
\text { attachment and ToM in siblings or controls. } \\
\text { Higher levels of childhood trauma were } \\
\text { significantly associated with emotion regulation } \\
\text { difficulties. }\end{array}$ & 5 \\
\hline $\begin{array}{l}\text { Fletcher } \\
\text { et al.,2014 } \\
\text { [63] }\end{array}$ & $\begin{array}{l}\mathrm{BD} I \mathrm{I}=24(\mathrm{NR}) \\
\mathrm{BPD}=24(\mathrm{NR})\end{array}$ & $\begin{array}{l}\text { Both groups= } \\
32.9(11.3)\end{array}$ & MOPS & CERQ; DERS & $\begin{array}{l}\text { Dysfunctional parenting experiences were } \\
\text { significantly associated with emotion regulation } \\
\text { difficulties. }\end{array}$ & 4 \\
\hline $\begin{array}{l}\text { Nazarov } \\
\text { et al., } \\
\text { (2014) } \\
\text { [64] }\end{array}$ & $\begin{array}{l}\text { PTSD }=31 \text { (all } \\
\text { female) } \\
\mathrm{HC}=20 \text { (all } \\
\text { female) }\end{array}$ & $\begin{array}{l}\mathrm{PTSD}=42.1(12.0) \\
\mathrm{HC}=35.8(13.2)\end{array}$ & CTQ; PBI & RMET; IPT-15 & $\begin{array}{l}\text { Childhood trauma was significantly associated } \\
\text { with difficulties on the IPT- } 15 \text { task in patients. }\end{array}$ & 5 \\
\hline $\begin{array}{l}\text { Nicol } \\
\text { et al.,2014 } \\
\text { [65] }\end{array}$ & $\begin{array}{l}\mathrm{BPD}=20(5: 15) \\
\mathrm{HC}=21(5: 16)\end{array}$ & $\begin{array}{l}\mathrm{BPD}=34.3(8.5) \\
\mathrm{HC}=34.5(11.6)\end{array}$ & CTQ & Ekman 60 faces test & $\begin{array}{l}\text { In the patient group, a history of childhood } \\
\text { trauma, specifically emotional and physical } \\
\text { abuse, was significantly associated with deficits } \\
\text { in recognising disgust. }\end{array}$ & 4 \\
\hline $\begin{array}{l}\text { Carvalho } \\
\text { Fernando } \\
\text { et al.,2014 } \\
\text { [66] }\end{array}$ & $\begin{array}{l}\mathrm{BPD}=49(5: 44) \\
\mathrm{MDD}=48 \\
(22: 26) \\
\mathrm{HC}=63(22: 41)\end{array}$ & $\begin{array}{l}\mathrm{BPD}=28.63 \\
(8.99) \\
\mathrm{MDD}=33.15 \\
(8.89) \\
\mathrm{HC}=31.44(9.98)\end{array}$ & CTQ & ERQ; DERS & $\begin{array}{l}\text { Childhood trauma experiences, specifically } \\
\text { emotional abuse and neglect, were significantly } \\
\text { associated with emotion regulation difficulties } \\
\text { in both patients and controls. }\end{array}$ & 4 \\
\hline $\begin{array}{l}\text { Scott } \\
\text { et al.,2013 } \\
\text { [67] }\end{array}$ & $\begin{array}{l}\mathrm{BPD}=100 \\
(35: 65)\end{array}$ & $\mathrm{BPD}=45.9(10.6)$ & AAPR & EERI & $\begin{array}{l}\text { Preoccupied (anxious) attachment was } \\
\text { significantly associated with emotion regulation } \\
\text { difficulties. }\end{array}$ & 3 \\
\hline $\begin{array}{l}\text { Zheng } \\
\text { et al.,2011 } \\
\text { [68] }\end{array}$ & $\begin{array}{l}\text { Patients with } \\
\text { personality } \\
\text { disorders } \\
123(61: 62) \\
\mathrm{HC}=166 \\
(82: 84)\end{array}$ & $\begin{array}{l}\text { Patients with } \\
\text { personality } \\
\text { disorders } \\
24.42(7.03) \\
\mathrm{HC}=23.24(3.86)\end{array}$ & PBI & JACFEE & $\begin{array}{l}\text { In patients and healthy controls, maternal care } \\
\text { significantly predicted the accuracy of } \\
\text { recognising sadness. } \\
\text { Paternal care negatively predicted the accuracy } \\
\text { of recognising anger in patients. } \\
\text { In the control group, the maternal autonomy } \\
\text { denial significantly predicted the accuracy of } \\
\text { recognizing sadness. }\end{array}$ & 4 \\
\hline $\begin{array}{l}\text { MaBeth } \\
\text { et al.,2011 } \\
\text { [69] }\end{array}$ & $\mathrm{FEP}=34(20: 14)$ & NR & AAI & $\mathrm{RF}$ & $\begin{array}{l}\text { Patients with secure and insecure/preoccupied } \\
\text { attachment styles showed significantly higher } \\
\text { RF than those with insecure/dismissing } \\
\text { (avoidant) classifications. }\end{array}$ & 3 \\
\hline $\begin{array}{l}\text { Lysaker } \\
\text { et al.,2011 } \\
\text { [70] }\end{array}$ & $\begin{array}{l}\mathrm{SZ} / \mathrm{SZD}=101 \\
(86: 15)\end{array}$ & $S Z=46.26(9.66)$ & TAA & MAS; BLERT & $\begin{array}{l}\text { Patients with a history of childhood sexual } \\
\text { abuse had lower awareness of other people's } \\
\text { emotions than those without this history. }\end{array}$ & 3 \\
\hline $\begin{array}{l}\text { Preissler } \\
\text { et al. } \\
\text { (2010) } \\
\text { [71] }\end{array}$ & $\begin{array}{l}\mathrm{BPD}=64 \text { (all } \\
\text { female) } \\
\mathrm{HC}=38 \text { (all } \\
\text { female) }\end{array}$ & $\begin{array}{l}\mathrm{BPD}=29.2(8.9) \\
\mathrm{HC}=31.7(10.3)\end{array}$ & PDS & RMET; MASC & $\begin{array}{l}\text { Experience of sexual trauma significantly } \\
\text { negatively predicted social cognitive abilities on } \\
\text { the MASC in patients. }\end{array}$ & 6 \\
\hline $\begin{array}{l}\text { Donohoe } \\
\text { et al.,2008 }\end{array}$ & $\begin{array}{l}\text { SZ/SZD }=73 \\
{[(749: 24)} \\
\mathrm{HC}=78(45: 33)\end{array}$ & $\begin{array}{l}\mathrm{SZ}=41.4(11.5) \\
\mathrm{HC}=38.3(13.5)\end{array}$ & RQ & IPSAQ & $\begin{array}{l}\text { Secure attachment was significantly associated } \\
\text { with lower 'personalising bias' scores in the } \\
\text { patient group only. }\end{array}$ & 4 \\
\hline
\end{tabular}

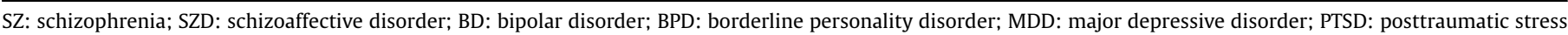

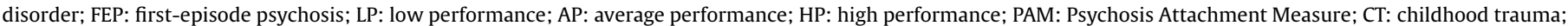

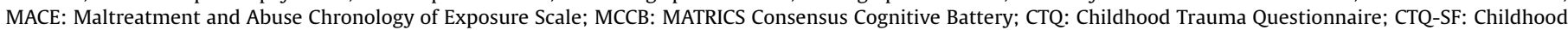

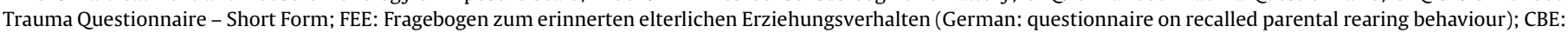

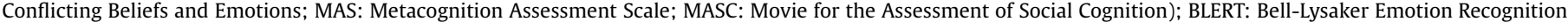

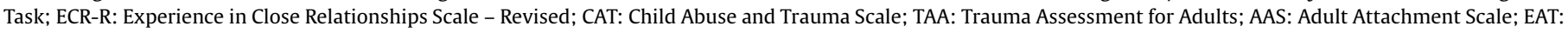

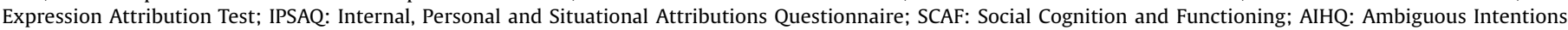

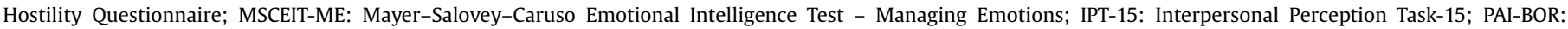

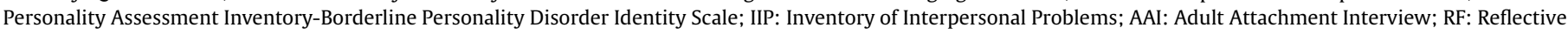

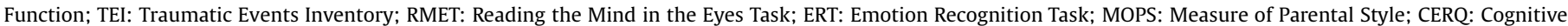

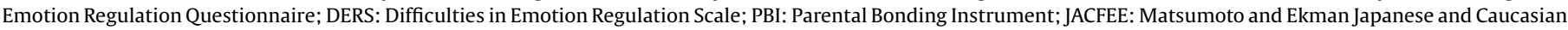

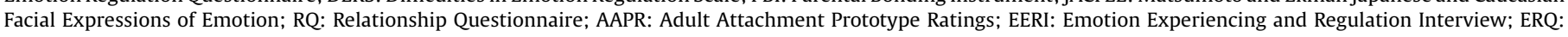
Emotion Regulation Questionnaire; ToM; Theory of Mind; NR: not reported.

* gender and mean age was reported for three different cluster groups.

** non-affected siblings of patients.

${ }^{* * *} 67$ participants with PTSD symptoms (30\% of the sample met diagnostic criteria for PTSD).

paranoid $(n=13)$, schizoid $(n=26)$, schizotypal $(n=14)$, antisocial $(n=8)$, borderline $(n=7)$, histrionic $(n=18)$, $\operatorname{narcissistic}(n=3)$, avoidant $(n=14)$, dependent $(n=8)$, or obsessive-compulsive $(\mathrm{n}=12)$ personality disorders. 
the patient group but not in healthy controls. Several studies since then have examined the link between (childhood) attachment/ parental bonding styles and social cognitive outcomes in patients with an established psychotic disorder. Pos et al. [61] reported that avoidant attachment (measured with the Psychosis Attachment Measure; PAM [80]) was significantly associated with cognitive (second order) and affective (first and second order) ToM in patients with a diagnosis of schizophrenia spectrum disorder $(n=111)$. Additionally, anxious attachment was linked to poorer performance in cognitive ToM (second order). Neither anxious nor avoidant attachment styles were associated with ToM measures in non-affected siblings $(n=106)$ or healthy controls $(n=63)$. By contrast, Olbert et al. [53], who again used the PAM to assess the relationship between adult attachment style and social cognition in 138 patients with schizophrenia, found no correlations between these measures. The authors suggest that these findings may reflect construct validity issues with the PAM, the psychometric properties and construct validity in terms of measuring ToM.

In terms of association with early adversity, Lysaker et al. [70] investigated the relationship with social cognition in 67 patients with schizophrenia and 34 patients with schizoaffective disorder (a healthy participant group was not included in the study). Based on this analysis, the authors found that the group aware of their own emotions but not those of others had a significantly higher report of childhood sexual abuse. Significant associations were also reported in the study by Schalinski et al. [48] comprised of 168 patients with schizophrenia spectrum disorders and 50 healthy controls. The results highlighted a negative impact of adverse childhood experiences, specifically physical neglect at age 11 , on social cognitive function in schizophrenia. Similarly, Garcia et al. [54] found a negative correlation between higher early life adversity total scores and ToM total scores in FEP patients and Kilian et al. [49] provided additional evidence for the association between adverse life events and social cognition as they found that childhood neglect was a significant predictor of social cognitive deficits in the same population of patients. By contrast, in an analysis of the relationship between childhood adversity and social functioning in small clinical groups (20 patients with chronic schizophrenia, 30 FEP patients and 14 ultra-high risk individuals) and a larger healthy control group, Palmier-Claus et al. [52] found that childhood adversity, as measured by the CTQ [76], did not significantly predict performance on either measure of ToM (Reading the Mind in the Eyes Task, Hinting Task) in any of the statistical models they tested.

\subsubsection{Bipolar disorder}

Further, in a sample of 75 patients with bipolar disorder, Russo et al. [75] found that traumatic childhood experiences, specifically emotional neglect and physical abuse, resulted in impairments in the recognition of angry faces in comparison to those with no such history. A trend level association was also observed for physical neglect. A healthy comparison group was not included in this study. By comparison, a similar study by Jiménez et al. [51] investigating the association between childhood trauma and cognitive performance in a sample of 113 bipolar patients did not fully replicate findings by Russo and colleagues [75] as they only observed a non-significant trend toward an association between physical neglect and social cognition (measured with the Managing Emotions branch of the MSCEIT [81]). However, as suggested by the authors, these findings may be due to the fact that the social cognitive tasks they used did not sufficiently measure this specific domain of social cognition.

\subsubsection{Borderline personality disorder}

In a sample of age and gender matched patients with bipolar disorder II $(n=24)$ and borderline personality disorder $(n=24)$,
Fletcher et al. [43] investigated the relationship between perceived parental style and emotional self-regulation showing a significant association between dysfunctional parenting experiences and maladaptive emotion regulation strategies. Another study conducted by Zheng et al. [61] in 123 patients with various personality disorders and 166 healthy controls, found that parental care significantly predicted emotional accuracy in patients and controls. Specifically, better maternal care was associated with greater accuracy in recognising expressions of sadness, whereas worse quality of paternal care was significantly associated with better recognition of anger. Significant associations were also reported in the study by Scott et al. [51] comprised of 100 patients with borderline personality disorder ( 35 males and 65 females), with no comparison control group. The authors showed that preoccupied (anxious) attachment style and difficulties with emotion regulation were significantly positively associated. More recently, Beeney et al. [57] provided additional evidence for the relationship between attachment insecurities and social cognition as they reported a link between insecure attachments and deficits in mentalization in a sample of 150 patients with borderline personality disorder. Furthermore, Brüne et al. [61] found that ToM was associated with parenting style, childhood trauma and attachment style in the patient group based on a study of 30 female borderline personality disorder patients and 30 female healthy controls. Specifically, poorer affective ToM performance was associated with lack of maternal emotional warmth, rejection and punishment, physical neglect and abuse, emotional neglect and preoccupied attachment style. Detrimental effects of childhood trauma, specifically sexual abuse and punishment, on ToM abilities were also reported by Preissler et al. [71], and more recently by Petersen et al. [56] based on 64 and 19 patients with borderline personality disorder, respectively. Likewise, in the study comprised of 20 borderline personality disorder patients and 21 healthy controls, Nicol et al. [44] reported a significant association between a childhood history of emotional and physical abuse, and poorer emotional recognition - specifically, identification of disgust. Finally, another study on childhood adversity conducted by Carvalho Fernando [62] explored the association between selfreported childhood traumatic experiences and emotional selfregulation in a sample of 49 borderline personality disorder and 48 major depressive disorder patients and 63 healthy controls. They observed that maltreatment experiences, especially emotional neglect and abuse, were significantly associated with poorer emotional self-regulation in both patients and healthy controls, as measured with the Emotion Regulation Questionnaire [63] and the Difficulties in Emotion Regulation Scale [64].

\subsubsection{Major depressive disorder}

Evidence for the association between childhood adversity and social cognitive functioning was also provided by Günther et al. [58] in a sample of 45 patients with major depressive disorder; no healthy participants were included in the study. The authors reported that more severe maltreatment during childhood resulted in moodcongruent biases in emotion processing (i.e. sustained attention toward sad facial expressions). In terms of the association with attachment, Koelkebeck et al. [50] showed that dependent and anxious attachment styles were related to lower scores on the ToM task in 38 patients with major depressive disorder patients suggesting that trustful and less dependent attachment in relationships may result in better social cognitive abilities.

\subsubsection{Posttraumatic stress disorder}

Three further studies have examined the association between adverse early social environment and social cognition in patients with posttraumatic stress disorder. The first study by Powers et al. [74] conducted in 67 individuals with PTSD symptoms (19 of which 
met diagnostic criteria for PTSD) and comparing individuals with low and high childhood trauma reported that moderate-to-severe childhood abuse was significantly related to worse emotional regulation scores. This finding was independent of current PTSD symptoms, depressive symptoms, and adult trauma exposure. Furthermore, Nazarov et al. [64] demonstrated, in a sample of female patients with PTSD $(\mathrm{n}=31)$ and matched healthy controls $(n=20)$, that traumatic childhood experiences in individuals with PTSD were associated with difficulties interpreting scenes depicting kinship interactions, as measured with the Interpersonal Perception Task-15 [82]. Finally, in the subsequent and similarly sized study by Nazarov et al. [60] examining the ability to discriminate affective prosody in women with PTSD and healthy controls, the authors observed that childhood maltreatment (specifically emotional abuse, emotional and physical neglect) was related to less accurate discrimination and slower identification of emotions.

\section{Discussion}

The main aim of this review was to synthesise the literature exploring the association between early life environment (i.e. attachment, childhood trauma) and social cognition in individuals with a diagnosis of either schizophrenia, bipolar disorder, borderline personality disorder, major depressive disorder and/ or posttraumatic stress disorder. Thus, we conducted a systematic search of the literature, which identified 25 relevant studies. Of these studies, nine were conducted in patients with schizophrenia spectrum disorders, seven in patients with personality disorders, four in patients with affective disorders, three in patients with anxiety disorders and two in mixed groups of patients with either affective or personality disorders. This literature is relatively recent, with the first study being published ten years ago [72], with an apparent growth in the numbers of articles published, which indicates an increased interest in the topic.

The majority of the studies reviewed showed a significant association between early childhood experience, including both sub-optimal parenting and childhood adversity relating to neglect or abuse, and poorer social cognition. Together, these data suggest that these negative early social experiences deleteriously impact on later social cognitive function in patients, and to some extent in healthy participants also. Specifically, emotional and physical abuse, neglect, and avoidant attachment styles were found to be the strongest predictors of ToM, emotion recognition deficits, and emotional dysregulation. The only studies $(n=3)$ that did not report this relationship were either based on small sample sizes $(\mathrm{n}<30)$ [52] which were likely to have been underpowered, employed a measure of attachment with unclear construct validity [53] or used a task that was not sufficient to measure a specific domain of social cognition [51].

Some limitations should be acknowledged regarding the generalisability of the data reviewed in this study. Firstly, a number of studies were based on small sample sizes, which may not have been sufficiently powered for detecting small effects regarding the relationship between adverse early life environment and social cognition. Secondly, the majority of the studies included either poorly matched control groups or no control groups at all, thus limiting the generalisability and reliability of findings. In particular, this made it difficult to determine whether there were differential effects of early social environment on social cognition according to status as patient or healthy controls, or between patient groups. Thirdly, these studies were conducted in patients of different age groups and phases of the illness (e.g. FEP, chronic). While this has the advantage of reflecting the effects of social cognition on a broader population, the effects on different illness phases are unknown. Another limitation of the studies reviewed here is that the early childhood experiences were assessed through subjective retrospective measures affecting potentially the accuracy of these reports. A number of studies have previously provided strong support for the validity and reliability of the retrospective self-reports of childhood maltreatment [83-85]. However, an important factor that has yet to be addressed is whether and to what extent age of onset and frequency of traumatic experiences moderate their effects $[9,86]$. Finally, social cognitive measures used in the studies were considerably heterogeneous, thus preventing us from conducting a meta-analysis. Notwithstanding these limitations, and as already noted, the vast majority of the studies provided firm evidence of the significant effects of early childhood environment on social cognitive functioning.

\subsection{Early social environment and social cognitive deficits in major psychiatric disorders: an attachment perspective}

As noted in our introduction, Attachment theory [26] provides a framework for understanding the potential cognitive mechanisms behind this relationship between early social environment and social cognition. This theory proposes that typical social, cognitive and emotional development is formed on the basis of an attachment bond with the caregiver, which provides a child with the inputs from which internal representations of others and self are constructed. If the attachment process is disrupted, for instance by a traumatic event, the child may not develop the secure base essential to form and maintain relationships throughout life and acquire social cognitive skills.

The results of our review are complimentary to existing evidence of a strong link between adverse parental experience and childhood trauma and mental health problems in adulthood. In particular, exposure to early life stress has been frequently shown to increase the risk for psychosis [87,88], bipolar disorder $[89,90]$, borderline personality disorder $[13,91]$, major depressive disorder [92,93] and posttraumatic stress disorder [94]. There is also consistent evidence that childhood adversity, specifically emotional abuse, is associated with clinical characteristics of these disorders, including an earlier onset of the illness [95,96], an increased risk of at least one lifetime suicide attempt [97,98], and higher symptom severity $[86,99,100]$. Because social cognitive abilities are likely to be acquired through interaction with primary caregivers and the broader environment, insecure attachment and traumatic experiences in early developmental stages may disrupt their development. Thus, social cognitive impairments may be a possible pathway through which childhood adversities increase the risk for developing psychiatric disorders and act as a mediator between negative early life experiences and later psychopathology. A direct link between social cognition and symptoms is suggested by the fact that many psychotic symptoms, such as auditory hallucinations or reasoning biases, referred to as jumping to conclusions', can be a result of attribution of one's actions, feelings and thoughts to external sources and impaired mentalising abilities, respectively [101].

\subsection{Early social environment and social cognitive development in major psychiatric disorders: biological factors}

Since the era of candidate gene studies, the relationship between early life adversity, genetic risk and phenotypic variation has been a subject of great interest to the field of psychiatric genetics. Two genetic variants previously associated with psychiatric risk receiving particular attention have been the Serotonin transporter gene (5-HTT) and the BDNF Val66Met polymorphism. While the potential role for 5-HTT in mediating the effects of early adversity on later outcomes was first highlighted by Caspi et al. [102], the role of this variant has remained controversial, and unsupported in a meta-analysis by Risch et al. [103]. To our 
knowledge, no social cognition studies in humans have been carried out that test the interactive effects of 5-HTT and early adversity, although evidence from animal studies point to cognitive effects [104]. Similarly, we found only one study of the interaction between early adversity and the Val66Met polymorphism at BDNF in relation to cognition [105], but a measure of social cognition was not included in this study.

Independent of early environment, variation at several genomic loci has been implicated in social cognition, both for specific disorders (e.g. in Schizophrenia with variants within ZNF804A [106] and MIR137 [107]) and across disorders (e.g. Oxytocin; for a recent review see Kendrick et al. [108]). To date, however, and to our knowledge, no studies have tested the interaction between social cognition, early adversity, and genome wide associated risk loci for psychiatric disorders. This remains a priority for future research that seeks to model the relationship between early adversity and genetic risk in contribution to social cognitive development.

Patients with major psychiatric disorders reporting a history of early adversity have also been found to show increased hyperactivity of the hypothalamic-pituitary-adrenal (HPA) axis as compared to those with no prior experience of maltreatment $[109,110]$. Furthermore, there is some evidence that this relationship may be conditional on genetic variation at the 5-HTT locus [111-113]. This hyperactivity of the HPA axis is thought to affect the neural growth in developmentally sensitive structures and function of brain regions with a high density of glucocorticoid receptors (e.g. hippocampus and prefrontal cortex [114]) as well as regions sensitive to repeated neuronal excitation (e.g. amygdala [115]). These structural and functional changes may result in disruption of cognitive processes, specifically memory, learning, and social information processing [116]. Chronically elevated corticosterone levels resulting from early life adversities have also been found to hinder the integrity of ventral and dorsal medial prefrontal cortex, which comprise the 'neural circuitry of self, leading to disruptions in self-referential and selfmonitoring processes [117]. Furthermore, in major psychiatric disorders, a history of childhood abuse has been associated with decreased grey matter in brain areas involved in social cognitive processes, i.e. dorsolateral prefrontal cortex, ventromedial prefrontal cortex, and amygdala [118-122]. Although smaller gray matter volume is found in several brain regions associated with higher cognitive processes in all patients with psychiatric disorders, the experience of childhood trauma appears to be an additional risk factor for gray matter loss [119]. Numerous studies have also shown that childhood adversities contribute to functional brain alterations that may lead result in social cognitive deficits. For instance, Quidé and colleagues [123] reported a positive association between early life trauma and activation of the dorsomedial prefrontal cortex in schizophrenia and an increased amygdala activation was reported by Hentze et al. [124] in trauma-exposed patients with chronic depression during an affective ToM task. Additionally, in a recent study involving patients with schizophrenia, Cancel et al. [125] has found that during an emotional valence task, childhood trauma was negatively associated with decreased connectivity between the amygdala and the precuneus, the posterior cingulate cortex and the calcarine sulcus, all of which are involved in theory of mind.

\section{Conclusion}

Deficits in social cognition are suggested to represent a core aspect of disability in psychiatric disorders such as Schizophrenia, and may be more predictive of psychosocial functioning than general cognitive ability [126]. The fact that these deficits are not generally improved by antipsychotic medication [127,128] makes social cognition an important treatment target, and makes the development of a causal working model of social cognitive deficits of crucial importance.
This systematic review provides a comprehensive picture of current research on the relationship between early life environment and social cognition in patients with major psychiatric disorders. The studies reviewed suggest a crucial role of early childhood experiences in the development of social cognitive abilities, which may represent a mediator between early life adversities and later symptom severity. Studies to understand the mechanisms by which this occurs at neurocognitive and biological levels remain an important goal for the field. Alongside these research needs, the findings of this review underline the importance of addressing the various types of early childhood social experiences and adversity in clinical assessment and interventions, given the abundant evidence of the later effects of these experiences. Finally, the studies reviewed are relevant from a public health perspective, highlighting the importance of early childhood interventions (e.g. parenting programs) that seek to minimise the occurrence and long term effects of adversity in early life.

\section{Funding}

This work was funded by grants to GD from the European Research Council (ERC-2015-STG-677467) and Science Foundation Ireland (SFI-16/ERCS/3787).

\section{Conflict of interest}

None to declare.

\section{Appendix A. Supplementary data}

Supplementary material related to this article can be found, in the online version, at doi:https://doi.org/10.1016/j.eurpsy.2018.06.006.

\section{References}

[1] Briere J., Elliott DM. Prevalence and psychological sequelae of self-reported childhood physical and sexual abuse in a general population sample of men and women. Child Abuse Neglect 2003;27:1205-22.

[2] Kessler RC, McLaughlin KA, Green JG, Gruber MJ, Sampson NA, Zaslavsky AM, et al. Childhood adversities and adult psychopathology in the WHO world mental health surveys. Br J Psychiatry: J Ment Sci 2010;197:378-85.

[3] Wolff N, Shi J. Childhood and adult trauma experiences of incarcerated persons and their relationship to adult behavioral health problems and treatment. Int J Environ Res Public Health 2012;9:1908-26.

[4] Kendler KS, Bulik CM, Silberg J, Hettema JM, Myers J, Prescott CA. Childhood sexual abuse and adult psychiatric and substance use disorders in women: an epidemiological and cotwin control analysis. Arch Gen Psychiatry 2000;57:953-9.

[5] Lieberman AF, Knorr K. The impact of trauma: a developmental framework for infancy and early childhood. Pediatric Ann 2007;36:209-15.

[6] Read J, Perry BD, Moskowitz A, Connolly J. The contribution of early traumatic events to schizophrenia in some patients: a traumagenic neurodevelopmental model. Psychiatry 2001;64:319-45.

[7] Aas M, Henry C, Andreassen OA, Bellivier F, Melle I, Etain B. The role of childhood trauma in bipolar disorders. Int J Bipolar Disord 2016;4:2.

[8] Herman JL, Perry JC, van der Kolk BA. Childhood trauma in borderline personality disorder. Am J Psychiatry 1989;146:490-5.

[9] Maercker A, Michael T, Fehm L, Becker ES, Margraf J. Age of traumatisation as a predictor of post-traumatic stress disorder or major depression in young women. Br. J Psychiatry: J Ment Sci 2004;184:482-7.

[10] Bebbington P. Childhood sexual abuse and psychosis: aetiology and mechanism. Epidemiol Psichiatr Soc 2009;18:284-93.

[11] Read J, Fosse R, Moskowitz A, Perry B. The traumagenic neurodevelopmental model of psychosis revisited. 2014

[12] Larsson S, Andreassen OA, Aas M, Rossberg JI, Mork E, Steen NE, et al. High prevalence of childhood trauma in patients with schizophrenia spectrum and affective disorder. Compr Psychiatry 2013;54:123-7.

[13] Battle CL, Shea MT, Johnson DM, Yen S, Zlotnick C, Zanarini MC, et al Childhood maltreatment associated with adult personality disorders: findings from the collaborative longitudinal personality disorders study. J Pers Disord 2004; 18:193-211.

[14] Kessler RC, Aguilar-Gaxiola S, Alonso J, Benjet C, Bromet EJ, Cardoso G, et al. Trauma and PTSD in the WHO world mental health surveys. Eur J Psychotraumatol 2017;8:1353383. 
[15] Taillieu TL, Brownridge DA, Sareen J, Afifi TO. Childhood emotional maltreatment and mental disorders: results from a nationally representative adult sample from the United States. Child Abuse Neglect 2016;59:1-12.

[16] Young JC, Widom CS. Long-term effects of child abuse and neglect on emotion processing in adulthood. Child Abuse Neglect 2014;38:1369-81.

[17] Bartholomew K. Avoidance of intimacy: an attachment perspective.] Soc Pers Relat 1990;7:147-78.

[18] Morgan C, Kirkbride J, Leff J, Craig T, Hutchinson G, McKenzie K, et al. Parental separation, loss and psychosis in different ethnic groups: a case-control study. Psychological Med 2007;37:495-503.

[19] Dozier M, Stovall-McClough CE, Albus K. Attachment and psychopathology in adulthood. 2008.

[20] Schreier A, Wolke D, Thomas K, Horwood J, Hollis C, Gunnell D, et al. Prospective study of peer victimization in childhood and psychotic symptoms in a nonclinical population at age 12 years. Arch Gen Psychiatry 2009;66:527-36.

[21] Stalker CA, Davies F. Attachment organization and adaptation in sexuallyabused women. Can J Psychiatry Rev canadienne de Psychiatrie 1995;40:234-40.

[22] Alexander PC. The differential effects of abuse characteristics and attachment in the prediction of long-term effects of sexual abuse. J Interpers Violence 1993;8:346-62.

[23] Styron T, Janoff-Bulman R. Childhood attachment and abuse: long-term effects on adult attachment, depression, and conflict resolution. Child Abuse Neglect 1997;21:1015-23.

[24] Erozkan A. The link between types of attachment and childhood trauma. 2016.

[25] Fonagy P, Target M. Attachment, trauma, and psychoanalysis: where psychoanalysis meets neuroscience. 2008 .

[26] Bowlby J. Attachment and loss. 1. Attachment: basic books. 1969.

[27] Bowlby J. Attachment and loss: separation: anxiety and anger: basic books. 1973.

[28] Cyr C, Euser EM, Bakermans-Kranenburg MJ, Van Ijzendoorn MH. Attachment security and disorganization in maltreating and high-risk families: a series of meta-analyses. Dev Psychopathol 2010;22:87-108.

[29] Lieberman AF, Chu A, Van Horn P, Harris WW. Trauma in early childhood: empirical evidence and clinical implications. Dev Psychopathol 2011;23:397-410.

[30] Ainsworth MDS. Attachment as related to mother-infant interaction. In: Rosenblatt JS, Hinde RA, Beer C, Busnel M-C, editors. Advances in the study of behavior. Academic Press; 1979. p. 1-51.

[31] Bowlby J. Attachment and loss ; 3. Loss, sadness and depression. Hogarth Press; 1980.

[32] Vandevivere E, Braet C, Bosmans G, Mueller SC, De Raedt R. Attachment and children's biased attentional processing: evidence for the exclusion of attachment-related information. PloS One 2014;9:e103476.

[33] Vanwoerden S, Kalpakci AH, Sharp C. Experiential avoidance mediates the link between maternal attachment style and theory of mind. Compr Psychiatry 2015;57:117-24.

[34] Bower GH, Sivers H. Cognitive impact of traumatic events. Dev Psychopathol 1998; 10:625-53.

[35] Pine DS, Mogg K, Bradley BP, Montgomery L, Monk CS, McClure E, et al. Attention bias to threat in maltreated children: implications for vulnerability to stress-related psychopathology. Am J Psychiatry 2005;162:291-6.

[36] Bugental D, Blue J, Lewis J. Caregiver beliefs and dysphoric affect directed to difficult children. 1990.

[37] Carlson V, Cicchetti D, Barnett D, Braunwald K. Disorganized/Disoriented attachment relationships in maltreated infants. 1989.

[38] Salzinger S, Feldman RS, Hammer M, Rosario M. The effects of physical abuse on children's social relationships. Child Dev 1993;64:169-87.

[39] Young JC, Widom CS. Long-term effects of child abuse and neglect on emotion processing in adulthood. Child Abuse Neglect 2014;38:1369-81.

[40] Pollak SD, Vardi S, Putzer Bechner AM, Curtin JJ. Physically abused children's regulation of attention in response to hostility. Child Dev 2005;76:968-77.

[41] Pollak SD, Cicchetti D, Hornung K, Reed A. Recognizing emotion in faces: developmental effects of child abuse and neglect. Dev Psychol 2000;36:679-88.

[42] Curtis WJ, Cicchetti D. Affective facial expression processing in young children who have experienced maltreatment during the first year of life: an event-related potential study. Dev Psychopathol 2011;23:373-95.

[43] Green MF. Impact of cognitive and social cognitive impairment on functional outcomes in patients with schizophrenia.JClin Psychiatry 2016;77(Suppl2):8-11.

[44] Henry JD, von Hippel W, Molenberghs P, Lee T, Sachdev PS. Clinical assessment of social cognitive function in neurological disorders. Nat Rev Neurol 2016;12:28-39.

[45] Bauer IE, Pascoe MC, Wollenhaupt-Aguiar B, Kapczinski F, Soares JC. Inflammatory mediators of cognitive impairment in bipolar disorder. J Psychiatric Res 2014;56:18-27.

[46] Misiak B, Stanczykiewicz B, Kotowicz K, Rybakowski JK, Samochowiec ]. Frydecka D. Cytokines and C-reactive protein alterations with respect to cognitive impairment in schizophrenia and bipolar disorder: a systematic review. Schizophrenia Res 2017.

[47] Moher D, Liberati A, Tetzlaff J, Altman DG. Preferred reporting items for systematic reviews and meta-analyses: the PRISMA statement. Ann Intern Med 2009;151:264-9 w64.

[48] Schalinski I, Teicher MH, Carolus AM, Rockstroh B. Defining the impact of childhood adversities on cognitive deficits in psychosis: an exploratory analysis. Schizophrenia research. 2017 No Pagination Specified.
[49] Kilian S, Asmal L, Chiliza B, Olivier MR, Phahladira L, Scheffler F, et al. Childhood adversity and cognitive function in schizophrenia spectrum disorders and healthy controls: evidence for an association between neglect and social cognition. Psychol Med 2017 No Pagination Specified.

[50] Koelkebeck K, Liedtke C, Kohl W, Alferink J, Kret ME. Attachment style moderates theory of mind abilities in depression. J Affect Disord. 2017;213:156-60.

[51] Jimenez E, Sole B, Arias B, Mitjans M, Varo C, Reinares M, et al. Impact of childhood trauma on cognitive profile in bipolar disorder. Bipolar Disord 2017;19:363-74.

[52] Palmier-Claus J, Berry K, Darrell-Berry H, Emsley R, Parker S, Drake R, et al. Childhood adversity and social functioning in psychosis: exploring clinical and cognitive mediators. Psychiatry Res 2016;238:25-32.

[53] Olbert CM, Penn DL, Reise SP, Horan WP, Kern RS, Lee J, et al. Assessment of attachment in psychosis: a psychometric cause for concern. Psychiatry Res 2016;246:77-83.

[54] Garcia M, Montalvo I, Creus M, Cabezas A, Sole M, Algora MJ, et al. Sex differences in the effect of childhood trauma on the clinical expression of early psychosis. Compr Psychiatry 2016;68:86-96.

[55] Brune M, Walden S, Edel MA, Dimaggio G. Mentalization of complex emotions in borderline personality disorder: the impact of parenting and exposure to trauma on the performance in a novel cartoon-based task. Compr Psychiatry 2016;64:29-37.

[56] Petersen R, Brakoulias V, Langdon R. An experimental investigation of mentalization ability in borderline personality disorder. Compr Psychiatry 2016:64:12-21.

[57] Beeney JE, Stepp SD, Hallquist MN, Scott LN, Wright AG, Ellison WD, et al. Attachment and social cognition in borderline personality disorder: specificity in relation to antisocial and avoidant personality disorders. Person Disord 2015;6:207-15.

[58] Gunther V, Dannlowski U, Kersting A, Suslow T. Associations between childhood maltreatment and emotion processing biases in major depression: results from a dot-probe task. BMC Psychiatry 2015;15:123.

[59] Russo M, Mahon K, Shanahan M, Solon C, Ramjas E, Turpin J, et al. The association between childhood trauma and facial emotion recognition in adults with bipolar disorder. Psychiatry Res 2015;229:771-6.

[60] Nazarov A, Frewen P, Oremus C, Schellenberg EG, McKinnon MC, Lanius R. Comprehension of affective prosody in women with post-traumatic stress disorder related to childhood abuse. Acta Psychiatr Scand 2015;131:342-9.

[61] Pos K, Bartels-Velthuis AA, Simons CJ, Korver-Nieberg N, Meijer CJ, de Haan L. Theory of mind and attachment styles in people with psychotic disorders, their siblings, and controls. Aust N Z J Psychiatry 2015;49:171-80.

[62] Powers A, Etkin A, Gyurak A, Bradley B, Jovanovic T. Associations between childhood abuse, posttraumatic stress disorder, and implicit emotion regulation deficits: evidence from a low-income, inner-city population. Psychiatry: Interpers Biol Processes 2015;78:251-64.

[63] Fletcher K, Parker G, Bayes A, Paterson A, McClure G. Emotion regulation strategies in bipolar II disorder and borderline personality disorder: differences and relationships with perceived parental style. J Affect Disord 2014;157:52-9.

[64] Nazarov A, Frewen P, Parlar M, Oremus C, MacQueen G, McKinnon M, et al. Theory of mind performance in women with posttraumatic stress disorder related to childhood abuse. Acta Psychiatr Scand 2014;129:193-201.

[65] Nicol K, Pope M, Hall J. Facial emotion recognition in borderline personality: an association, with childhood experience. Psychiatry Res 2014;218:256-8.

[66] Carvalho Fernando S, Beblo T, Schlosser N, Terfehr K, Otte C, Lowe B, et al. The impact of self-reported childhood trauma on emotion regulation in borderline personality disorder and major depression. J Trauma Dissociation 2014:15:384-401.

[67] Scott LN, Kim Y, Nolf KA, Hallquist MN, Wright AG, Stepp SD, et al. Preoccupied attachment and emotional dysregulation: specific aspects of borderline personality disorder or general dimensions of personality pathology? J Pers Disord 2013;27:473-95.

[68] Zheng L, Chai H, Chen W, Yu R, He W, Jiang Z, et al. Recognition of facial emotion and perceived parental bonding styles in healthy volunteers and personality disorder patients. Psychiatry Clin Neurosci 2011;65:648-54.

[69] MaBeth A, Gumley A, Schwannauer M, Fisher R. Attachment states of mind, mentalization, and their correlates in a first-episode psychosis sample. Psychol Psychother 2011:84:42-57 discussion 98-110.

[70] Lysaker PH, Gumley A, Brune M, Vanheule S, Buck KD, Dimaggio G. Deficits in the ability to recognize one's own affects and those of others: associations with neurocognition, symptoms and sexual trauma among persons with schizophrenia spectrum disorders. Conscious Cognit 2011:20:1183-92.

[71] Preißler S, Dziobek I, Ritter K, Heekeren HR, Roepke S. Social cognition in borderline personality disorder: evidence for disturbed recognition of the emotions, thoughts, and intentions of others. Front Behav Neurosci 2010:4:182.

[72] Donohoe G, Spoletini I, McGlade N, Behan C, Hayden J, O'Donoghue T, et al. Are relational style and neuropsychological performance predictors of social attributions in chronic schizophrenia? Psychiatry Res 2008;161:19-27.

[73] Association AP. Diagnostic and statistical manual of mental disorders. Text revision (DSM-IV-TR). 4th edition American Psychiatric Association; 2000.

[74] Powers A, Etkin A, Gyurak A, Bradley B, Jovanovic T. Associations between childhood abuse, posttraumatic stress disorder, and implicit emotion regulation deficits: evidence from a low-income, inner-city population. Psychiatry 2015;78:251-64.

[75] Russo M, Mahon K, Shanahan M, Solon C, Ramjas E, Turpin J, et al. The association between childhood trauma and facial emotion recognition in adults with bipolar disorder. Psychiatry Res 2015;229:771-6. 
[76] Bernstein DP, Ahluvalia T, Pogge D, Handelsman L. Validity of the childhood trauma questionnaire in an adolescent psychiatric population. J Am Acad Child Adolesc Psychiatry 1997;36:340-8.

[77] Bartholomew K, Horowitz LM. Attachment styles among young adults: a test of a four-category model. J Pers Soc Psychol 1991;61:226-44.

[78] Baron-Cohen S, Wheelwright S, Hill J, Raste Y, Plumb I. The "Reading the mind in the eyes" test revised version: a study with normal adults, and adults with asperger syndrome or high-functioning autism. J Child Psychol Psychiatry Allied Discipl 2001;42:241-51.

[79] Robbins TW, James M, Owen AM, Sahakian BJ, McInnes L, Rabbitt P. Cambridge neuropsychological test automated battery (CANTAB): a factor analytic study of a large sample of normal elderly volunteers. Dementia (Basel, Switzerland) 1994;5:266-81.

[80] Berry K, Wearden A, Barrowclough C. Adult attachment styles and psychosis: an investigation of associations between general attachment styles and attachment relationships with specific others. 2008.

[81] Brackett MA, Salovey P. Measuring emotional intelligence with the mayersalovery-caruso emotional intelligence test (MSCEIT). Psicothema 2006; (Suppl. 18):34-41.

[82] Costanzo M, Archer D. Interperting the expressive behavior of others: the interpersonal perception task. J Nonverbal Behav 1989;13:225-45.

[83] Dill DL, Chu JA, Grob MC, Eisen SV. The reliability of abuse history reports: a comparison of two inquiry formats. Compr Psychiatry 1991;32:166-9.

[84] Hardt J, Vellaisamy P, Schoon I. Sequelae of prospective versus retrospective reports of adverse childhood experiences. Psychol Rep 2010;107:425-40.

[85] Hardt J, Rutter M. Validity of adult retrospective reports of adverse childhood experiences: review of the evidence. J Child Psychol Psychiatry Allied Discip 2004:45:260-73.

[86] Hagenaars MA, Fisch I, van Minnen A. The effect of trauma onset and frequency on PTSD-associated symptoms. J Affect Disord 2011;132:192-9.

[87] Janssen I, Krabbendam L, Bak M, Hanssen M, Vollebergh W, de Graaf R, et al. Childhood abuse as a risk factor for psychotic experiences. Acta Psychiatr Scand 2004;109:38-45.

[88] Bebbington P, Jonas S, Kuipers E, King M, Cooper C, Brugha T, et al. Childhood sexual abuse and psychosis: data from a cross-sectional national psychiatric survey in England. Br J Psychiatry : J Ment Sci 2011;199:29-37.

[89] Etain B, Henry C, Bellivier F, Mathieu F, Leboyer M. Beyond genetics: childhood affective trauma in bipolar disorder. Bipolar Disord 2008;10:867-76.

[90] Fisher H, Hosang G. Childhood maltreatment and bipolar disorder: a critical review of the evidence. 2010.

[91] Zanarini MC, Williams AA, Lewis RE, Reich RB, Vera SC, Marino MF, et al. Reported pathological childhood experiences associated with the development of borderline personality disorder. Am J Psychiatry 1997;154:1101-6.

[92] Molnar BE, Buka SL, Kessler RC. Child sexual abuse and subsequent psychopathology: results from the national comorbidity survey. Am J Public Health 2001:91:753-60.

[93] Widom CS, DuMont K, Czaja SJ. A prospective investigation of major depressive disorder and comorbidity in abused and neglected children grown up. Arch Gen Psychiatry 2007;64:49-56.

[94] Widom CS. Posttraumatic stress disorder in abused and neglected children grown up. Am J Psychiatry 1999;156:1223-9.

[95] Darves-Bornoz JM, Lempérière T, Degiovanni A, Gaillard P. Sexual victimization in women with schizophrenia and bipolar disorder. Soc Psychiatry Psychiatr Epidemiol 1995;30:78-84.

[96] Li XB, Liu JT, Zhu XZ, Zhang L, Tang YL, Wang CY. Childhood trauma associates with clinical features of bipolar disorder in a sample of Chinese patients. J Affect Disorders 2014;168:58-63.

[97] Alvarez MJ, Roura P, Oses A, Foguet Q, Sola J, Arrufat FX. Prevalence and clinical impact of childhood trauma in patients with severe mental disorders. J Nerv Ment Dis 2011;199:156-61.

[98] Etain B, Aas M, Andreassen OA, Lorentzen S, Dieset I, Gard S, et al. Childhood trauma is associated with severe clinical characteristics of bipolar disorders. J Clin Psychiatry 2013;74:991-8.

[99] Bentall RP, Wickham S, Shevlin M, Varese F. Do specific early-life adversities lead to specific symptoms of psychosis? A study from the 2007 the adult psychiatric morbidity survey. Schizophr Bull 2012;38:734-40.

[100] Martins CM, Von Werne Baes C, Tofoli SM, Juruena MF. Emotional abuse in childhood is a differential factor for the development of depression in adults. J Nerv Ment Dis 2014;202:774-82.

[101] van Os J, Kenis G, Rutten BP. The environment and schizophrenia. Nature 2010;468:203-12.

[102] Caspi A, Sugden K, Moffitt TE, Taylor A, Craig IW, Harrington H, et al. Influence of life stress on depression: moderation by a polymorphism in the 5-HTT gene. Science (New York, NY) 2003:301:386-9.

[103] Risch N, Herrell R, Lehner T, Liang KY, Eaves L, Hoh J, et al. Interaction between the serotonin transporter gene (5-HTTLPR), stressful life events, and risk of depression: a meta-analysis. JAMA 2009;301:2462-71.

[104] Robbins TW. Neurobehavioural sequelae of social deprivation in rodents revisited: modelling social adversity for developmental neuropsychiatric disorders. J Psychopharmacol (Oxford, England) 2016;30:1082-9.

[105] Aas M, Haukvik UK, Djurovic S, Bergmann O, Athanasiu L, Tesli MS, et al. BDNF val66met modulates the association between childhood trauma, cognitive and brain abnormalities in psychoses. Progress Neuro-Psychopharmacol Biol Psychiatry 2013;46:181-8.
[106] Hargreaves A, Morris DW, Rose E, Fahey C, Moore S, Cummings E, et al ZNF804A and social cognition in patients with schizophrenia and healthy controls. Mol Psychiatry 2012;17:118-9.

[107] Mothersill O, Morris DW, Kelly S, Rose EJ, Fahey C, O'Brien C, et al. Effects of MIR137 on fronto-amygdala functional connectivity. NeuroImage 2014;90:189-95.

[108] Kendrick KM, Guastella AJ, Becker B. Overview of human oxytocin research. Current topics in behavioral neurosciences. 2017.

[109] Braehler C, Holowka D, Brunet A, Beaulieu S, Baptista T, Debruille JB, et al. Diurnal cortisol in schizophrenia patients with childhood trauma. Schizophr Res 2005;79:353-4.

[110] Peng H, Long Y, Li J, Guo Y, Wu H, Yang Y, et al. Hypothalamic-pituitaryadrenal axis functioning and dysfunctional attitude in depressed patients with and without childhood neglect. BMC Psychiatry 2014;14: 45-

[111] Alexander N, Kuepper Y, Schmitz A, Osinsky R, Kozyra E, Hennig J. Geneenvironment interactions predict cortisol responses after acute stress: implications for the etiology of depression. Psychoneuroendocrinology 2009:34:1294-303.

[112] Gotlib IH, Joormann J, Minor KL, Hallmayer J. HPA axis reactivity: a mechanism underlying the associations among 5-HTTLPR, stress, and depression. Biol Psychiatry 2008;63:847-51.

[113] Lardinois M, Lataster T, Mengelers R, Van Os J, Myin-Germeys I. Childhood trauma and increased stress sensitivity in psychosis. Acta Psychiatr Scand 2011;123:28-35.

[114] Zhu L-J, Liu M-Y, Li H, Liu X, Chen C, Han Z, et al. The different roles of glucocorticoids in the hippocampus and hypothalamus in chronic stressinduced HPA axis hyperactivity. PLoS One 2014;9:e97689.

[115] Mothersill O, Donohoe G. Neural effects of social environmental stress - an activation likelihood estimation meta-analysis. Psychol Med 2016:46:2015-23.

[116] Walder DJ, Walker EF, Lewine RJ. Cognitive functioning, cortisol release, and symptom severity in patients with schizophrenia. Biol Psychiatry 2000:48:1121-32.

[117] Brent BK, Seidman LJ, Thermenos HW, Holt DJ, Keshavan MS. Selfdisturbances as a possible premorbid indicator of schizophrenia risk: a neurodevelopmental perspective. Schizophr Res 2014;152:, doi:http://dx. doi.org/10.1016/j.schres.2013.07.038.

[118] Aas M, Navari S, Gibbs A, Mondelli V, Fisher HL, Morgan C, et al. Is there a link between childhood trauma, cognition, and amygdala and hippocampus volume in first-episode psychosis? Schizophr Res 2012;137:73-9.

[119] Sheffield JM, Williams LE, Woodward ND, Heckers S. Reduced gray matter volume in psychotic disorder patients with a history of childhood sexual abuse. Schizophr Res 2013;143:185-91.

[120] Keding TJ, Herringa RJ. Abnormal structure of fear circuitry in pediatric posttraumatic stress disorder. Neuropsychopharmacology 2015;40:537-45.

[121] Wise T, Radua J, Via E, Cardoner N, Abe O, Adams TM, et al. Common and distinct patterns of grey-matter volume alteration in major depression and bipolar disorder: evidence from voxel-based meta-analysis. Mol Psychiatry 2016;22:1455.

[122] Aguilar-Ortiz S, Salgado-Pineda P, Marco-Pallarés J, Pascual JC, Vega D, Soler J, et al. Abnormalities in gray matter volume in patients with borderline personality disorder and their relation to lifetime depression: a VBM study. PloS One 2018;13:e0191946.

[123] Quide Y, Ong XH, Mohnke S, Schnell K, Walter H, Carr VJ, et al. Childhood trauma-related alterations in brain function during a theory-of-mind task in schizophrenia. Schizophr Res 2017;189:162-8.

[124] Hentze C, Walter H, Schramm E, Drost S, Schoepf D, Fangmeier T, et al. Functional correlates of childhood maltreatment and symptom severity during affective theory of mind tasks in chronic depression. PSychiatry Res Neuroimaging 2016;250:1-11.

[125] Cancel A, Comte M, Boutet C, Schneider FC, Rousseau PF, Boukezzi S, et al Childhood trauma and emotional processing circuits in schizophrenia: a functional connectivity study. Schizophr Res 2017;184:69-72.

[126] McGlade N, Behan C, Hayden J, O’Donoghue T, Peel R, Haq F, et al. Mental state decoding v. Mental state reasoning as a mediator between cognitive and social function in psychosis. Br J Psychiatry: J Ment Sci 2008;193:77-8.

[127] Daros AR, Ruocco AC, Reilly JL, Harris MS, Sweeney JA. Facial emotion recognition in first-episode schizophrenia and bipolar disorder with psychosis. Schizophr Res 2014;153:32-7.

[128] Kucharska-Pietura K, Mortimer A. Can antipsychotics improve social cognition in patients with schizophrenia? CNS Drugs 2013;27:335-43.

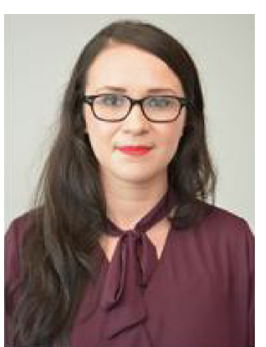

Karolina I. Rokita graduated with a MSc in Cognitive Neuroscience from Aston University (UK) in 2014. Following this, she worked as a Research Assistant at the Faculty of Health and Life Sciences at Coventry University on a collaborative project with University of Oxford. She is currently a PhD student at the Department of Psychology at the National University of Ireland, Galway. In her research, she uses neuropsychological and neuroimaging methods to examine the impact of early life experiences on social cognition in schizophrenia. 


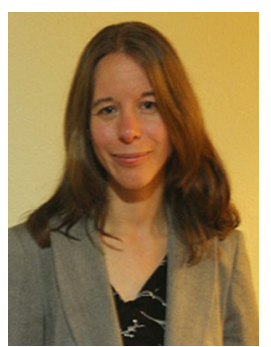

Dr. Maria R. Dauvermann is a postdoctoral researcher at the National University of Ireland in Galway. Maria received her $\mathrm{PhD}$ in Psychiatry and Neuroimaging from the University of Edinburgh in 2014. Following the PhD, Maria undertook postdoctoral research at the Massachusetts Institute of Technology until June 2016. Maria studies the impact of acute and chronic stress on functions of the brain and its relationship with clinical symptoms and cognitive deficits that may affect individuals in daily life by using in-vivo neuroimaging techniques, including functional Magnetic Resonance Imaging and Electroencephalogram.

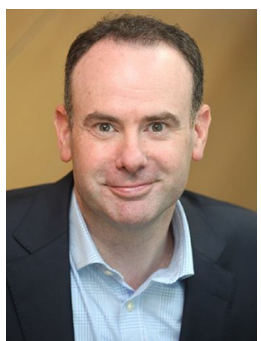

Prof. Gary Donohoe was appointed professor and chair of Psychology at NUI Galway in 2013. His research group (CogGene) studies how brain structure and function are affected by genetic risk factors. To do this, his work draws on neuropsychological, electrophysiological, and neuroimaging techniques for investigating the role of gene function at the level of individual brain systems. This work has led to a number of important insights into newly discovered risk genes for psychosis. Gary's research group is also actively involved in developing psychological therapies for major mental health disorders, including therapies that address cognitive deficits in schizophrenia. 